\title{
Tree Root Ecology in the Urban Environment and Implications for a Sustainable Rhizosphere
}

\author{
Susan D. Day, P. Eric Wiseman, Sarah B. Dickinson, and J. Roger Harris
}

\begin{abstract}
This review examines current understandings of how the belowground characteristics of urban settings affect tree roots as well as how tree roots contribute to biogeochemical processes in this belowground environment. Soil characteristics common to the urban environment include soil compaction and other physical impediments to root exploration, elevated $\mathrm{pH}$, altered temperature and moisture patterns, and the presence of contaminants. These conditions may alter the growth dynamics, morphology, and physiology of roots. At the same time, roots have a profound effect on the soil environment, with trees directing 40\%-73\% of assimilated carbon below ground. Urban rhizosphere ecology is a topic of renewed interest for research not only because of its critical role in the urban ecosystem, but also because of its role in global environmental issues. In addition to its obvious contribution to aboveground growth, root exploration of the soil environment can influence environmental sustainability through root contributions to soil structure and drainage. Root influence is further mediated by the intimate role of roots in soil biological activity and thus carbon storage and nutrient cycling. Current advances and implications for emerging research are discussed. Key Words. Heavy Metals; Road Salt; Root Periodicity; Soil Compaction; Soil Structure; Urban Hydrology; Urban Infrastructure.
\end{abstract}

The root-soil environment-the urban rhizosphere-is critical not only to tree health, but to urban ecosystem function as well. The performance of urban trees depends upon the ability of their root systems to acquire resources and provide anchorage. However, conditions prevalent in the built environment, such as compacted soils, underground infrastructure, chemical contamination, and excessive heat, create a unique and often unaccommodating environment that may impair root growth and development. In addition, practices associated with establishing and maintaining a landscape, such as transplanting large trees and employing irrigation systems, can alter tree root growth dynamics. In turn, tree roots alter the belowground environment through their influence on biological, physical, and chemical soil properties. This urban rhizosphere ecology has implications for both establishing trees in cities, and for assessing potential ecosystem services that trees, and their root systems in particular, provide to society. The scope of this review includes root responses to environmental elements typical of urban settings (for example, soil compaction) and root interactions with that environment through carbon deposition and other means. This paper avoids discussion of root architecture and specific root management practices (e.g., directing roots with barriers or planting space designs, root pruning, fertilization), and instead focuses on root ecological interactions with the environment. These interactions include growth periodicity; root response to physical constraints and soil chemical and biological properties; and root contributions to characteristics of the belowground environment that relate to contemporary discussions of environmental sustainability, such as carbon sequestration, erosion control, and soil hydrological processes. The purpose of this paper is to provide a review of the literature in this emerging area of inquiry in the context of arboriculture and urban forestry that will help identify knowledge gaps and inform future research.

\section{ROOT GROWTH PERIODICITY-RESPONSES TO TRANSPLANTING, SOIL TEMPERATURE, AND SEASON} Root growth, especially fine root production and mortality, is a dominant feature of the belowground ecosystem where trees are present. In arboriculture and urban forestry, the question "When do tree roots grow?" has been largely addressed in the context of transplanting (Harris et al. 2001; Harris et al. 2002; Richardson-Calfee et al. 2007; Richardson-Calfee et al. 2008), where tree establishment depends upon root exploration of the new site (Harris 2007) and can be influenced considerably by transplant time (Richardson-Calfee et al. 2004).

Mathematical modeling of root growth periodicity has shown that resource limitation feedback between shoot and root growth results in a balance between the two processes that is favorable to tree growth in the particular environment where it is located (Thornley 1972; Thaler and Pagés 1998). Investigators have reported that many temperate woody plants exhibit pronounced periods of root elongation in autumn and spring, although activity level will decline during shoot expansion as resources are allocated to aboveground parts (Stone and Schubert 1959; Stone et al. 1962; Cripps 1970 Roberts 1976; Deans 1979; Dell and Wallace 1983; Wargo 1983; Deans and Ford 1986; Harris et al. 1995; Harris and Fanelli 1999). Although root growth is clearly linked to shoot growth by endogenous signals (Richardson 1958; Larson and Whitmore 1970; Farmer 1975), climate, local weather, and soil conditions are key factors controlling these root growth periods. In particular, root growth is strongly influenced by soil temperature and moisture (Lyr and Hoffman 1967). Each species has a different amplitude, or "ideal" range, of soil temperature that is suitable for root growth. This range usually corresponds to the climate of the region where the species (or species ecotype) is native. The typical temperature range that permits root growth 
for temperate zone species is between $2{ }^{\circ} \mathrm{C}$ and $25^{\circ} \mathrm{C}$ (Lyr and Hoffman 1967). Root elongation of many temperate species is severely limited when soil temperatures fall below $10^{\circ} \mathrm{C}$ (Harris et al. 1995; Harris et al. 1996). In contrast to their shoots, which have a dormant period that can only be overcome by chilling, the roots of many temperate zone trees do not exhibit an easily identified period of innate dormancy (Richardson 1958; Taylor and Dumbroff 1975), and can respond quickly to warming soil. However, Arnold and Young (1990) found evidence with several Malus (apple) species that an innate root dormancy satisfied by low temperature exposure may exist in some tree species. Lack of moisture suppresses root growth in two ways: first by restricting water uptake that drives cell expansion, and second by increasing soil strength (see Compacted Soil as a Permeable Impediment). For trees in tropical areas, water availability is the main environmental determinant for periodic root growth patterns (Borchert 1994), and root biomass is strongly correlated with soil moisture across tropical moisture gradients (Green et al. 2005; McGroddy and Silver 2009). In temperate species, soil moisture dynamics influence root growth periodicity within the confines of temperature controls (Tesky and Hinkley 1981; Kuhns et al. 1985).

\section{ROOT RESPONSE TO PHYSICAL CONSTRAINTS}

The ability of roots to explore the belowground environment in urban settings influences tree health, stability, and longevity. However, few studies have addressed rooting response of urban trees to specific characteristics of the belowground environment (for a general view of root architecture in urban settings, see Day et al. 2010). In a study encompassing seven German cities, 20to 40-year-old Tilia spp. (lindens, species not identified) were excavated in an attempt to identify belowground factors that influenced root penetration and proliferation (Krieter 1986). One unusual facet of this large-scale study was the excavation of potential rooting spaces under streets and sidewalks. Root penetration and fine root proliferation were influenced by soil type. Both pure sands and gravel layers (no fine materials) as well as highly compacted loamy and clayey soils restricted or prevented root penetration (see also Soil Compaction). Greater fine root proliferation was observed within irrigated areas, around utility and irrigation lines, in areas with coarse gravel and debris mixed with finer materials (clay and silt), and at curb interfaces and similar structures where a physical "dam" was created that may have collected water. Even with this large-scale study, however, variation was considerable, and the root responses observed may have been unique to German street tree installation practices, to the northern European climate, or to the particular tree species.

As this study demonstrates, there are multiple physical constraints that dictate root exploration of the subterranean urban environment. These constraints can be broadly classified into two types: solid impediments such as building foundations, roads, and rocks; and permeable impediments, such as compacted soils. Root exploration of these physical obstructions may further depend upon moisture content.

\section{Urban Infrastructure as a Solid Impediment}

In urban conditions, tree root systems may be confined by belowground infrastructure that is essentially impenetrable unless seams, cracks, or other openings are present. Studies in urban and landscape settings documenting tree root growth in and around this infrastructure are extremely limited. Nonetheless, the following examples illustrate the potential for roots to navigate minute fissures in the urban underground complex. In a case study describing management of root-infrastructure conflicts, Schroeder (2005) published a photo of Acer pseudoplatanus (sycamore maple) fibrous roots penetrating through mortar joints into an underground utility room and extending $1 \mathrm{~m}$ or more through the air inside the chamber. Root interactions with sewer pipes have been reviewed by Randrup et al. (2001), who documented numerous intrusions by roots into unsealed pipes. Although tree roots may successfully explore belowground urban infrastructure, this does not necessarily mean that adequate nutrients and water can be obtained, and spatial availability of these resources can have a profound effect on root distribution (Mou et al. 1997).

Because research in urban settings is limited, we must rely on studies in analogous situations to provide additional insight into root response to physical constraints. For example, trees adapted to arid, rocky conditions may grow roots through very small cracks (less than $0.3 \mathrm{~cm}$ wide) in rock up to $9 \mathrm{~m}$ deep in order to access the water table (Saunier and Wagle 1967). In southwestern Oregon, U.S., roots were found in rock fissures as small as $100 \mu \mathrm{m}$ (Zwieniecki and Newton 1995). While the stele retains its regular shape under such confined conditions, the root cortex may become flat, creating wing-like structures on the sides of the stele (Saunier and Wagle 1967; Stone and Kalisz 1991; Zwieniecki and Newton 1995). These structures have been measured at up to $0.75 \mathrm{~mm}$ across with root hairs only occurring on the edges of the structures (Zwieniecki and Newton 1995). These studies illustrate how roots might penetrate minute fissures in concrete, masonry, or other urban infrastructure and adapt anatomically to the space. Documented observations in urban environments are few, and the conditions necessary for this adaptive growth are unknown. In some cases, tree roots will grow around physical obstacles. For example, Platanus $\times$ acerifolia roots were observed to partially or completely encapsulate $2 \mathrm{~cm}$ limestone gravel that was a component of a structural soil mix (Bassuk 2008).

\section{Compacted Soil as a Permeable Impediment}

Soil compaction arising from urban land development and use is a more pervasive cause of root restriction for landscape trees. Compaction occurs as soil is compressed, which degrades structure, diminishes porosity, and increases strengththe soil's physical resistance to penetration. Soil compaction in urban areas is widespread. In a study of 48 sites in Moscow, Idaho, and Pullman, Washington, recently developed sites were found to have higher soil bulk densities than older sites (Scharenbroch et al. 2005), presumably due to more stringent engineering standards and more effective compaction equipment. Site development practices often entail removal of upper soil horizons (especially O and A) during grading (Jim 1998), leaving denser subsoil at the surface, and the soil underlying pavement is typically compacted to provide structural support. Thus urban tree root systems are likely to encounter compacted soil. These restricted root systems are commonly shallower, confined by dense soil underlying pavement or planting pits, or exhibit less extensive soil exploration than would be possible in uncompacted soil. Root systems in compacted soil are more highly branched and consist of thicker, stubbier roots, which often results in shallower rooting depth (Tackett and Pearson 1964; Voorhees et al. 1975; Gilman et al. 1987; Materechera et al. 1991). 
Although bulk density indicates the degree of compaction for a particular soil, it does not provide a complete picture of root inhibition for that soil. Soil texture and moisture must also be considered along with bulk density, because these properties in combination determine soil strength (Taylor and Gardner 1963; Taylor and Ratliff 1969; Zisa et al. 1980; Daddow and Warrington 1983; Day et al. 2000). In their classic study, Daddow and Warrington (1983) used an in-depth survey of forest soil compaction research to create a chart depicting rootgrowth-limiting bulk density for each soil texture (i.e., the bulk density at which root growth would essentially halt for a given soil texture). As they note, this serves as a useful proxy for soil resistance to penetration, but does not account for other factors that affect soil strength, particularly moisture.

Soil strength is a function of bulk density and moisture content. As bulk density increases due to compaction, the frictional and cohesive forces between soil particles increase and thus soil strength increases (Greacen and Sands 1980). As soil strength increases, root elongation rate decreases due to resistance of soil particles to displacement (Clark et al. 2003). The critical soil strength (measured with a cone penetrometer) above which woody plant root elongation is severely restricted is in the vicinity of $2.3 \mathrm{MPa}$, depending on soil type and plant species (Day and Bassuk 1994). Soil moisture can alleviate excessive soil strength by lubricating soil particles and the elongating root tip. However, the moisture content required to alleviate excessive soil strength is progressively greater as bulk density increases. In sandy loam soil, the volumetric moisture content at which soil strength fell below the critical limit was about $20 \%$ at a bulk density of $1.18 \mathrm{~g} / \mathrm{cm}^{3}$ versus about $30 \%$ at a bulk density of $1.26 \mathrm{~g} / \mathrm{cm}^{3}$ (Siegel-Issem et al. 2005).

In compacted soil, the combination of increased volumetric water content, and decreased macroporosity limits gas diffusion and may cause root aeration stress. In silty loam soil compacted to $1.44 \mathrm{~g} / \mathrm{cm}^{3}$, root growth of shortleaf pine (Pinus echinata) is limited above $35 \%$ volumetric water content due to poor aeration (Siegel-Issem et al. 2005). In a loam soil compacted to $1.5 \mathrm{~g} / \mathrm{cm}^{3}$, root growth of Cornus florida (flowering dogwood) is depressed in very moist soils (matric tension of $0.006 \mathrm{MPa}$ and oxygen diffusion rates $<0.5 \mathrm{mg} \mathrm{cm}^{-2} \mathrm{~min}$ ), while roots of Acer saccharinum (silver maple) are not (Day et al. 2000). However, poor aeration due to low macroporosity in compacted soil may not be an issue in unsaturated soil (Day et al. 1995; Aust et al. 1998; Day et al. 2000).

Species vary in their ability to elongate roots in compacted soils. This is not simply attributable to differential ability to exert pressure on the soil, although slight differences have been demonstrated among species in controlled laboratory environments. For example, Materechera et al. (1991) evaluated root penetration of 22 crop species at an extreme soil strength of 4.2 $\mathrm{MPa}$ and found that all species had root elongation reduced between 92 and $98 \%$ and that the ability of a given species to penetrate strong soil was positively correlated with root diameter. At lower soil strength levels, species differences in root response to compaction can be easier to discern. For example, when soil strength is increased from 0 to $1.0 \mathrm{MPa}$, root elongation of peanuts is reduced by only $29 \%$ while elongation of cotton roots is reduced by $62 \%$ (Taylor and Ratliff (1969). However, low soil strengths such as these are unlikely to be encountered in the field except under wet conditions. These data illustrate that root growth of woody plants will be restricted with any increase in soil strength, rather than growing "normally" until a certain threshold is reached. In a recent study with native Australian Eucalyptus spp., root penetration decreased linearly as soil bulk density was increased from 1.0 to $1.4 \mathrm{~g} / \mathrm{cm}^{3}$ (soil texture not described), further demonstrating the immediate reduction in root penetration when soil compaction increases (Skinner et al. 2009).

Variation in species tolerance of soil compaction is currently conceived to be a complex response to the whole rooting environment. The strongest hypothesis for explaining the ability of certain tree species to tolerate compacted soil is the "root growth opportunity" hypothesis, which states that tree species tolerant of wet soils (e.g., bottomland species) can grow roots during wet periods when soil strength is low, while species less tolerant of wet soils (i.e., soil hypoxia) cannot. Thus bottomland species may be expected to have a greater root growth opportunity when soil strength is low, and thus be more adapted to soil compaction, such as is found in urban areas. Generalized models addressing this root growth opportunity were initially developed to integrate the limits of soil strength with the limits of soil water content into a single descriptor for evaluating soil quality for crop production (Letey 1985), and were eventually described as the Least Limiting Water Range (da Silva et al. 1994). Day et al. (2000) presented a similar hypothesis for urban trees and evaluated the root growth opportunity in the context of species tolerances via a study of silver maple (Acer sacharrinum) and flowering dogwood (Cornus florida). Siegel-Issem et al. (2005) further developed this approach as a measure of forest soil productivity. These last experiments evaluated the influence of soil strength, bulk density, soil moisture, and oxygen diffusion rate on seedling root growth, providing support for this hypothesis as an explanation for species response to compacted soils (Day et al. 2000; SiegelIssem et al. 2005). Yet, response to compacted soils is influenced by a host of environmental and genetic factors and species differences are not always easily explained (Bassett et al. 2005).

\section{ROOT RESPONSE TO SOIL CHEMISTRY AND CONTAMINANTS}

Urban soils typically have very different environmental inputs than rural or forested landscapes. These include anything related to intense human activity, such as de-icing salts, tire residue, engine oil, construction debris, landscape mulches, and lawn clippings. Many of these items alter soil chemistry. In addition, brownfields-land previously used for industrial, or sometimes other commercial, purposes that may have environmental contaminants-are prevalent in many countries (Oliver et al. 2005). Decisions concerning brownfield development receive more attention as land becomes more scarce (e.g., Altherr et al. 2007), and the numerous economic, social, and environmental benefits of urban greenspaces are better appreciated. In a Canadian study, uncertainty about the effects of soil contamination and approaches to its mitigation was ranked as the most important noneconomic barrier to developing these areas as greenspace (De Sousa 2003). Chemical contaminants are also common beyond brownfields. These include de-icing salt as well as heavy metals such as $\mathrm{Cu}, \mathrm{Pb}$, and $\mathrm{Zn}$ that are by-products of automobile traffic (Pouyat et al. 1995; Irvine et al. 2009). Thus, there is increasing need to broaden our knowledge of root interactions with chemically altered urban soils. 


\section{Adverse Soil pH}

While some instances of slightly lower $\mathrm{pH}$ in forested lands near urban cores have been documented (Pouyat et al. 1995), disturbed urban soils are rarely too acidic for satisfactory tree growth. Instead, soil alkalinity is a more common consequence of urbanization and therefore a more common impediment to tree health. The use of concrete and other calcareous construction materials is nearly universal in urban areas and the removal of topsoil and horizon mixing facilitates the increase in soil $\mathrm{pH}$. In Hong Kong, China, soils sampled from 100 locations around the city core had a mean $\mathrm{pH}$ of 8.68 (Jim 1998). Sampling of soil $\mathrm{pH}$ in the top $10 \mathrm{~cm}$ of mineral soil around the Virginia Tech central campus in Blacksburg, VA, by students during laboratory exercises in horticulture and forestry classes taught by two authors of this review revealed soil $\mathrm{pH}$ is always above 7.0 and as high as 8.3 , whereas nearby relatively undisturbed sites has surface soil $\mathrm{pH}$ of 5.9-6.2 and nearby disturbed roadside ditches a pH of 6.8-7.3 (Harris et al. 2008). A study of six urban landscapes in Moscow, ID, and Pullman, WA, found average $\mathrm{pH}$ ranges from 6.64 to 7.32 (Scharenbroch et al. 2005).

At higher soil $\mathrm{pH}$, many tree species suffer from micronutrient deficiencies $(\mathrm{B}, \mathrm{Cu}, \mathrm{Fe}, \mathrm{Mn}$, and $\mathrm{Zn}$ ) because these nutrients exist in insoluble forms that are unavailable to the plant (Mengel and Kirkby 2001). Availability of P is also reduced in alkaline soil. Elevated $\mathrm{pH}$ may also alter the composition and abundance of endomycorrhizal fungi that inhabit soil (Porter et al. 1987), which could influence root system colonization and therefore nutrient uptake capacity. On the other hand, soil alkalinity also reduces the solubility of certain elements such as $\mathrm{Al}$ and $\mathrm{Pb}$, which are toxic to tree roots.

Sensitivity to alkalinity-induced nutrient deficiencies differs among tree species. In even slightly alkaline soils, sensitive species such as Quercus palustris (pin oak) and Quercus phellos (willow oak) may develop interveinal chlorosis in response to $\mathrm{Fe}$ and $\mathrm{Mn}$ deficiency while others remain unaffected [e.g., Ulmus americana (American elm) and Platanus $\times$ acerifolia (London plane)] (Dirr 1998). Root adaptations have been identified in some tolerant species that enhance Fe uptake, one example being the production of a specialized enzyme to reduce Fe (Moog and Brüggemann 1994). An evaluation of olive tree cultivars and rootstocks indicated that tolerance of calcareous soils was conferred by the rootstock rather than the scion (Alcántara et al. 2003).

Because of the ubiquity of alkaline soils in urban settings and the varied sensitivity of tree species to these soils, lists have been published to assist practitioners in selecting tree species and cultivars that tolerate particular soil pH levels (e.g., Appleton and Chaplin 2001; Bassuk et al. 2009). These lists are based partly, although certainly not exclusively, on practitioner experience since research reports are limited on many trees. In orchard trees, a clear asymptotic relationship is apparent between extractable $\mathrm{Fe}$ in the soil and leaf chlorosis: leaf greenness increases rapidly with increasing extractable $\mathrm{Fe}$ until a maximum level is reached, at which point the relationship levels off (de Santiago et al. 2008). However, in some urban trees, iron deficiency chlorosis has not shown a strong relationship with soil $\mathrm{pH}$ (Watson and Himelick 2004) and therefore likely not with the associated variable of extractable soil Fe either, although this last relationship has not been reported. A host of root system stresses - including root severance can negatively affect Fe uptake by urban tree roots. This has real consequences for urban trees since Fe or Mn deficiency impairs photosynthetic capacity (Abadía et al. 1999), which may diminish tree growth and stress tolerance.

\section{Salt Contamination}

Salt contamination of soils can stunt or kill tree roots depending upon species sensitivity, environmental variables (soil physical and chemical properties, precipitation, light intensity, temperature), duration and timing of exposure, and severity of contamination (Headley and Bassuk 1991; Bernstein and Kafkafi 2002). Salt contamination can arise from meltwater or spray from deicing salts (Kayama et al. 2003), from saltwater intrusion into groundwater, from sea salt blown ashore in coastal areas, or even from repeated applications of sewage sludge (Usman et al. 2004). De-icing salt is a common soil contaminant in colder climates. $\mathrm{NaCl}$ is the most widely-available, cost-effective material for de-icing streets, sidewalks, and parking lots, although other formulations such as $\mathrm{CaCl}_{2}$ and $\mathrm{K}_{2} \mathrm{CO}_{3}$ are used. In Denmark, high road salt concentrations were found in soils within $2 \mathrm{~m}$ of roadways, but quickly dissipated at greater distances (Pedersen et al. 2000). When precipitation is abundant, salt does not persist in the top layers of soil and eventually leaches down to subsoil horizons and groundwater (for a review of the environmental effects road salt, including effects on vegetation, see Priority Substances List Assessment: Road Salt 2001).

Because of its agronomic importance, salt stress has been the subject of considerable research. Nonetheless, the physiological mechanisms for tolerance are varied and complex and likely represent expressions of multiple genes as well as other adaptive responses (for reviews, see Cheeseman 1988). Root growth is usually less sensitive to salt stress than shoot growth, resulting in a higher root:shoot ratio in salt-stressed plants (Cheeseman 1988). However, in landscape situations, tree roots can be subjected to acute salt shock when large amounts of roadside deicing salt are applied (Headley and Bassuk 1991). High levels of salinity impose two types of stress on roots; first, osmotic stress results from lowered water potential in the soil solution (desiccation), and second, ionic stress results from changes in concentrations of specific ions in the soil solution and inside growing tissues (toxicity). Root systems vary in their ability to tolerate salts; tolerant species may be able to selectively exclude salt ion uptake (Lloyd et al. 1987). However, few generalizations can be made. For example, in a study of grafted Citrus spp. (lemon trees), salinity reduced growth of some rootstocks more than others and in some cases physiological stress was governed primarily by toxic levels of $\mathrm{Na}^{+}$and $\mathrm{Cl}^{-}$in leaf tissue (Gimeno et al. 2009). Salinity can also alter the symbiotic relationship between the roots of woody plants and mycorrhizal fungi, but this is not well understood at this time (Tian et al. 2004; Porras-Soriano et al. 2009). Because of the economic importance of salt tolerance in food crops, research is quickly identifying plant mechanisms of salt tolerance and their genetic control (e.g., Papdi et al. 2009).

\section{Trace Elements and Heavy Metals}

Numerous trace elements are essential or beneficial for plant function, including $\mathrm{B}, \mathrm{Cu}, \mathrm{Fe}, \mathrm{Mn}, \mathrm{Mo}$, and $\mathrm{Zn}$ (essential); $\mathrm{Cl}$ and $\mathrm{Ni}$ (sometimes essential); and $\mathrm{Co}, \mathrm{I}, \mathrm{Na}, \mathrm{Si}$, and $\mathrm{V}$ (beneficial) (Marschner 1996; Mengel and Kirkby 2001). However, all these elements can be toxic when their concentrations are too high (Hagemeyer and Breckle 2002). Heavy metals are commonly 
found in urban soils. They persist in the environment and can accumulate over time to levels toxic to plants. Besides industry, vehicular traffic is the main source of metal pollutants. The highest levels occur near roads (Jim 1998) and levels decrease with distance from the roadside (Birch and Scollen 2003; Fakayode and Olu-Owolabi 2003). Although modern regulations have reduced $\mathrm{Pb}$ emitted from vehicles, it persists in the environment and may remain elevated in roadsides. Zinc from tires is another major contaminant associated with vehicular traffic (Roberts et al. 2006).

Excessive concentrations of trace elements or heavy metals cause phytotoxicity through several mechanisms, including changes in cell membrane permeability, interference with metabolic processes, and replacement of essential ions (Patra et al. 2004). In roots, metals inhibit growth by interfering with cell division or cell elongation (Hagemeyer and Breckle 2002). These negative effects on roots may translate directly to negative effects on aboveground physiological function. For example, $\mathrm{Hg}$ toxicity symptoms of spruce seedlings such as decreased transpiration and lowered chlorophyll content were attributed primarily to root injury (Godbold and Hutterman 1988). Enhanced lateral root formation and compact, dense root branching habit have been observed in response to increasing concentrations of $\mathrm{Pb}, \mathrm{Zn}$, Mn, Cd, and Cu (Kahle 1993; Hagemeyer and Breckle 2002). It is thought that injury to the root apex by metals diminishes apical dominance, thereby increasing lateral root primordia. Lead also interferes with root hair formation. For example, root hair formation in Fagus sylvatica (European beech) was strongly inhibited by $\mathrm{Pb}$ at a concentration of $44 \mathrm{ppm}$ and was completely eliminated at $283 \mathrm{ppm}$ (Kahle 1993). Although a reduction in root hair density is an adaptive response for decreasing absorption of heavy metals, absorption of water and nutrients will also likely be reduced. In addition, nutrient uptake may be further reduced because of direct ion competition from heavy metals. For example, Kahle (1993) found lower nutrient concentrations in roots of numerous tree species exposed to heavy metals due to both reduced uptake and increased membrane leakage. Thus heavy metals commonly found in urban areas may both reduce root exploration of the soil and restrict uptake of nutrients and water. For a discussion of heavy metal threshold concentrations that reduce root growth, see Kahle (1993). Metal phytotoxicity is tempered in soils with high $\mathrm{pH}, \mathrm{CEC}$, clay content, and organic matter because these conditions lower metal bioavailability (for reviews, see Kahle 1993; Sieghardt et al. 2005).

\section{Tolerance of heavy metals}

Plant tolerance of heavy metal toxicity varies among species and genotypes, and tolerance of one metal does not imply tolerance of all metals. Because of their relatively long life span, trees can accumulate large amounts of toxic elements when growing on contaminated soils. Moreover, they often lack the morphological and physiological adaptations possessed by herbaceous plants that regulate internal concentrations of toxic trace elements (Hagemeyer and Breckle 2002). Heavy metals are likely not uniformly accumulated in the root system. Violina et al. (1999), for example, found that $\mathrm{Pb}$ concentrations in grapevine (Vitis spp.) were highest in fine absorbing roots and much lower in older, woody roots. Trees that can survive on metal-rich sites may rely on phenotypic plasticity, which enables roots to avoid areas of high contamination (Lepp 1991; Turner and Dickinson 1993; Hagemeyer and Breckle 2002). On the other hand, tolerant ecotypes of some genera, such as Betula spp. (birch) and Salix spp. (willow), may exhibit multiple survival strategies, including synthesis of phytochelatins that immobilize metal ions within the plant, rapid root turnover, and metal ion exclusion (Kahle 1993), and can become dominant species on metal contaminated sites (Gallagher et al. 2008). Salix spp. are frequently employed in phytoremediation of soils, where plants are selected for their ability to accumulate heavy metals or other contaminants from the soil and later harvested and safely disposed (Pulford and Watson 2003).

\section{Organic Pollutants and Pesticides}

There are a number of synthetic organic compounds (commonly pesticides and industrial compounds/by-products) that are potential pollutants in urban settings, and some may persist in the environment. Toxic levels of industrial organics usually are a concern on sites that have historic industrial activity, but may also occur at accident "hotspots" such as along roadways and railways. Some pesticides can have a negative impact on nontarget soil organisms (Bunemann et al. 2006) and may therefore adversely affect root growth. Mycorrhizae, for example, are sensitive to certain pesticides, particularly fungicides. Container-grown Liriodendron tulipifera (tulip-poplar) inoculated with arbuscular mycorrhizal fungi and subsequently soil-drenched with benomyl fungicide had reduced growth and mycorrhizal colonization compared to their non-drenched counterparts (Verkade and Hamilton 1983).

\section{ROOT CONTRIBUTIONS TO ENVIRONMENTAL SUSTAINABILITY}

Tree roots have the potential to positively influence soil quality, hydrology, and biogeochemistry in urban settings. More specifically, the roots of trees improve soil physical properties; maintain or enhance soil organic matter, $\mathrm{N}_{2}$ fixation, and nutrient uptake from below the reach of crop roots; increase water infiltration and storage; decrease loss of nutrients to erosion and leaching; decrease soil acidity; and improve soil biological activity (Young 1997).

\section{Soil Structure}

There are many factors in the urban environment that contribute to degradation of soils and in particular, soil structure (see Compacted Soil as a Permeable Impediment). Thus, the potential of tree roots to influence soil structure is of considerable interest. Tree roots are primary contributors to the development of soil structure and, in the longer term, soil formation. This new appreciation of the influence of roots on soil is redefining and enlarging our concept of rhizosphere: the area where soil interacts directly with living roots (Richter et al. 2007). Tree root contributions to soil structure not only affect plant growth, but a host of other soil functions that provide ecosystem services such as stormwater runoff mitigation through enhanced soil permeability (Bramley et al. 2003; Bartens et al. 2008).

\section{Tree roots form soil macropores}

Tree roots aid in improving soil structure in several ways. One of the most significant plant-induced changes in soil structure is the formation of continuous macropores (i.e., channels) by penetrating roots (Angers and Caron 1998). A large proportion of pores formed by roots fall into the macropore range $(>30 \mu \mathrm{m})$ (Gibbs and Reid 1988). These macropores facilitate soil aera- 
tion and water percolation and storage as well as create zones of failure, which help fragment the soil, form aggregates, and decrease resistance for further root growth. Roots form macropores by creating compressive and shear stresses when growing through the soil matrix (Goss 1991). Radial pressure exerted by growing roots compresses adjacent soil (Dexter 1987), which enlarges existing pores and creates new ones. Bartens et al. (2008) demonstrated that live roots can create channels through compacted soils and vastly increase water infiltration, although flow may be greater once roots die and decay (Mitchell et al. 1995). As root decay occurs, tissue remnants and associated microflora coat pore walls, which may enhance water transport efficiency (Barley 1954; Yunusa et al. 2002).

\section{Tree roots aid in soil aggregate formation}

Aggregate stability, an indicator of soil structure, results from soil particle rearrangement, flocculation, and cementation; it is mediated by soil organic carbon, biota, ionic bridging, clay, and carbonates (Bronick and Lal 2005). Rhizosphere soil has been found to have greater aggregate stability than nonrhizosphere soil (Angers and Caron 1998), and is influenced by rhizosphere deposition as well as a number of root system attributes, including root length, mass, density, size distribution, turnover rate, and hyphal growth (Caravaca et al. 2002). Dorioz et al. (1993) observed that adsorption of water by roots promoted reorganization of the clay, characterized by oriented and compacted clay particles, and that this environment was very rich in root mucilage. "The outstanding effect of the rhizosphere on soil structure can be related to the rhizosphere as being the privileged site for growth for a wide range of microorganisms at various sizes, each of them organizing the material at its own scale" (Dorioz et al. 1993).

Tree roots can directly enhance aggregation by releasing a variety of compounds that have a cementing effect on soil particles (Bronick and Lal 2005). For example, polysaccharides from root tips can penetrate and impregnate surrounding soil up to $50 \mu \mathrm{m}$ while bacteria polysaccharides penetrate less than $1 \mu \mathrm{m}$ (Dorioz et al. 1993). Research suggests that the root exudate polygalaturonic acid (PGA) stabilizes soil by increasing strength of bonds between particles and decreasing wetting rate of soil via water repellency at the soil surface (Czarnes et al. 2000). Tree roots also indirectly contribute to soil aggregate formation and stability because their exudates are a food source for soil organisms, which in turn release their own exudates that contribute to soil aggregation (Tisdall et al. 1978). These exudates are also a food source for earthworms (Angers and Caron 1998), which create macropores as they burrow through the soil (Edwards et al. 1989).

\section{Soil strength and stability}

Tree root systems form part of a complex matrix that can stabilize soil and reduce erosion, both important contributions to environmental sustainability. Soil inhabited by plants dries more quickly due to transpiration; as a result, the soil has greater shear and tensile strength and the root/soil tangential resistance to slipping will be increased (Waldron and Dakessian 1982). Lower soil water content resulting from the presence of plants may also help soils resist compaction (Horn and Dexter 1989; Lafond et al. 1992). Deep-rooted woody vegetation extracts more water from greater soil depths than grassy vegetation (Bethlahmy 1962; Rogerson 1976; McColl 1977).
This deep water extraction and resulting wetting and drying cycles can cause shrinkage and strengthening of the soil.

In addition to drying soil, tree roots increase soil stability via mechanical reinforcement (Waldron and Dakessian 1981; Waldron and Dakessian 1982; Abe and Iwamoto 1986; Mamo and Bubenzer 2001a; Mamo and Bubenzer 2001b; Wynn and Mostaghimi 2006). Construction of highways and other infrastructure alters the natural terrain, often resulting in steep, barren slopes that pose a landslide hazard. Tree roots have been used as tools for slope reinforcement, either alone (Norris 2005), or in combination with engineered approaches (Naoto et al. 2008). Although herbaceous vegetation may provide more immediate cover and soil stabilization, woody plants may provide greater reinforcement strength. In a study comparing the shear resistance of soil inhabited by different plants, alfalfa and grass had a more immediate effect on sheer resistance than yellow pine, but the older pine roots were clearly superior to young alfalfa roots, and shearing resistance was proportional to the number and diameter of pine roots (Waldron and Dakessian; Waldron et al. 1983).

Trees can also play an important role in stream bank stabilization (Docker and Hubble 2008; Pollen-Bankhead et al. 2009). In urban areas, stormwater runoff results in widely fluctuating water levels in streams, leading to channel erosion and impaired water quality (Schoonover et al. 2006). An in situ study of vegetated stream banks showed that an increase in the volume of roots with diameters of 2-20 mm was correlated with reduced soil erodability (Wynn and Mostaghimi 2006). Wynn et al. (2004) compared root distribution and density in stream banks inhabited by both herbaceous and woody vegetation. Their findings suggest riparian forests may provide better protection against stream bank erosion than herbaceous buffers.

\section{Hydrology}

Impervious surfaces, soil compaction, and stormwater drains prevent dispersed infiltration of stormwater in the built environment, decreasing groundwater levels and stream baseflow (Kaye et al. 2006). Even unpaved urban soils can have much reduced infiltration rates compared to undeveloped land (Gregory et al. $2006)$. In vegetated areas, only $5 \%-15 \%$ of rainwater runs off the ground and the rest evaporates or infiltrates into the soil, whereas about $60 \%$ of rainfall in urban areas is exported through storm drains (Bolund and Hunhammar 1999). Older stormwater systems are often connected to sewers and when these stormwater systems overflow, untreated sewage pollutes surface waters. Even if storm drains are not connected to sewers, stormwater is still concentrated and not allowed to infiltrate in a dispersed fashion, thereby reducing the influence of plants and soil on water chemistry and increasing stream temperatures when stormwater is directly deposited into surface waters (Kaye et al. 2006).

Urban trees are well recognized as effective tools for mitigating urban runoff (Xiao et al. 2000; Xiao and McPherson 2003), but the specific role of the root system is largely unrecognized. Root systems aid in dispersal of stormwater into the soil by guiding stormwater along root channels, playing a primary role in base flow (Dasgupta et al. 2006; Johnson and Lehmann 2006), aiding in water infiltration (Bramley et al. 2003; Bartens et al. 2008), and absorbing water (Wullschleger et al. 1998; Szabo et al. 2001). In addition, hydraulic lift by tree roots may improve survival of other plant species in dry climates, thus enhancing the contribution of 
the plant community as a whole (Dawson 1993; Dawson 1996). In addition to "lifting" water, trees may redistribute water into deeper soil regions, possibly improving groundwater recharge (Burgess et al. 1998; Burgess et al. 2001). Tree roots may also have indirect effects on the hydrologic cycle through their role in nutrient and carbon cycling and improvements in soil structure.

\section{Nutrient Cycling}

Plant nutrient content of urban soils can range from highly deficient due to interrupted nutrient cycles and disturbed soils to overly abundant due to misapplication of fertilizers and other anthropogenic sources. Nitrogen deposition from the atmosphere has increased considerably over the past 150 years, and the consequences of this change are still uncertain (Holland et al. 2005). Urban ecosystems have been identified as sources of nutrient pollution to receiving waters (Boyer et al. 2002), particularly $\mathrm{N}$ and P. Urban and suburban watersheds have much higher $\mathrm{N}$ losses than completely forested watersheds (Groffman et al. 2004). The input of reactive $\mathrm{N}$ compounds in urban areas is also much higher than surrounding, less populated areas, with sources ranging from automobile engines and excessive $\mathrm{N}$ fertilization to pet urine and feces (Zhu et al. 2004). Rates of denitrification in urban areas can be very high compared to other ecosystems and $\mathrm{N}$ distribution is influenced by stormwater capture systems (Zhu et al. 2004). The effect of such nutrient hotspots on urban tree root systems is poorly documented. However, tree roots can help regulate nutrient cycles by influencing the supply and availability of nutrients in the soil via root turnover, root exudates, and nutrient uptake.

Trees can affect nutrient export by reducing stormwater runoff and soil erosion (see Hydrology); stormwater may carry nutrients as well as sediment laden with nutrients that may be tightly bound to soil (e.g., P). Trees can influence nutrient supply in the rhizosphere by biological $\mathrm{N}$ fixation, extracting nutrients especially nitrate - from below the root zone of other plants, and reducing nutrient losses from processes such as leaching and erosion (Buresh and Tian 1997; Jama et al. 1998). Roots influence a complex set of nitrogen transformations that regulate production, flow, and loss of $\mathrm{N}$ in ecosystems (Fornara et al. 2009). In a Jamaican study, proximity to Casuarina cunninghamiana (river sheoak) trees increased $\mathrm{N}, \mathrm{NO}_{3}$, organic matter, $\mathrm{P}, \mathrm{Mg}, \mathrm{K}, \mathrm{Ca}$, $\mathrm{pH}$, and CEC (Zimpfer et al. 1999). The researchers attributed this response to a complex symbiotic relationship with particular mycorrhizal species. On a global scale, nutrient cycling by plants alters vertical distribution of nutrients within the soil profile, keeping nutrients available nearer the soil surface (Jobbágy and Jackson 2001). For example, sloughed root cells and mucilage contain substantial amounts of soluble $\mathrm{C}$ and $\mathrm{N}$ (Jones et al. 2004), which is a source of energy for rhizosphere flora and fauna that in turn contribute to a consistent supply of $\mathrm{N}$ for plants.

\section{Carbon Cycling, Soil Organic Material, and C Sequestration}

Urban regions are large contributors to atmospheric $\mathrm{CO}_{2}$ enrichment because of both high emissions and fuel use and minimal $\mathrm{C}$ sequestration (Kaye et al. 2006). In addition, daily average atmospheric $\mathrm{CO}_{2}$ concentrations in city centers can exceed 500 ppm, whereas global mean concentrations are 379 ppm (Pataki et al. 2007; Lorenz and Lal 2009). Higher $\mathrm{CO}_{2}$ concentrations enhance plant growth (Gregg et al. 2003), and trees fix this $\mathrm{CO}_{2}$ via photo- synthesis and sequester it into the soil through litter and root inputs. Urban soils have the potential to store large amounts of rootsupplied soil organic carbon (SOC) and therefore to contribute to mitigation of increased atmospheric $\mathrm{CO}_{2}$ concentrations (Lorenz and Lal 2009). The amount of SOC that can be stored is highly variable - the SOC pool at 0.3-m depth may range between 16 and $232 \mathrm{Mg} / \mathrm{ha}$ and between 15 and $285 \mathrm{Mg} /$ ha at $1-\mathrm{m}$ depth (Lorenz and Lal 2009). SOC storage is also dependent on the local climate, land use, and parent material. For example, the cool, wet climate of northeastern United States favors higher accumulation of soil organic carbon than dry, rocky, arid climates (Pouyat et al. 2006).

The role of urban tree root systems in carbon storage has received limited attention, and research rests primarily on results from other ecosystems and laboratory studies. However, the potential for carbon storage through root deposition is considerable. Besides the deliberate incorporation of organic matter, carbon enters soil from plant litter, the release of carbon-rich root exudates, and root death along with associated mycorrhizae (i.e., turnover) (Grayston et al. 1997; Young 1998; Farrar et al. 2003). It has been estimated $2 \%-4 \%$ of net fixed $C$ in plants may be directly deposited into the soil via root exudates (for a review, see Jones et al. 2004). These carbon compounds can also be taken back up by the plant in a controlled fashion (Farrar et al. 2003). Trees direct a greater proportion of their fixed carbon below ground when compared to annual plants, with rates from $40 \%-73 \%$ of assimilated $\mathrm{C}$ being demonstrated in studies with trees (Grayston et al. 1997). Up to $47 \%$ of carbon allocated to fine roots and mycorrhizae is deposited into soils through root turnover (Fogel and Hunt 1983). Not only does SOC increase activity of microorganisms, but the presence of the microorganisms can initiate a feedback system that increases root exudation (Meharg and Killham 1991). Carbon from plant roots therefore exerts a large control on the soil microbial community and consequently on overall soil health (Brant and Myrold 2006).

As previously discussed, urban soils are often very inhospitable to root growth. Stripping urban land of its vegetation and topsoil, coupled with elevated temperatures, also depletes soil organic matter and consequently decreases soil microbial populations, particularly in newly disturbed soils (McDonnell et al. 1997; Scharenbroch et al. 2005). Soil microorganisms are very important to tree growth because they are critical drivers of nutrient cycling, $\mathrm{N}$ fixation, nitrification, and the aggregation of clay particles (i.e., building of soil structure) (Lee and Pankhurst 1992). Urban sites in Colorado, U.S., that were fertilized and irrigated had greater microbial biomass than adjacent agricultural land that was not fertilized or irrigated (Kaye et al. 2005). Takahashi et al. (2008) compared soil C concentrations of different land uses [turf, trees "with management" (weed and litter removal), and trees "without management" in urban parks], and found that at $0-10 \mathrm{~cm}$ soil depth there were similar soil C concentrations, but at 10-30 cm, average $\mathrm{C}$ concentrations were lower for turf than they were for trees "with management." Trees "without management" resulted in far greater soil $\mathrm{C}$ concentrations than the other land uses.

\section{CONCLUSIONS AND FUTURE RESEARCH}

This review has focused on the ecophysiology of tree roots in the urban environment and how they interact with this human-dominated world. There are many unanswered questions that relate to management of urban tree root systems, 
but comments here are confined to basic research questions that can provide a greater understanding of the role of the tree root system in the ecology of the urban rhizosphere. The following are proposed as possible areas of future research:

1. Biological community in the larger rhizosphere. Evidence is abundant that tree root systems cannot be fully understood separately from the microorganisms that inhabit the larger rhizosphere. Yet, we know little about these communities and how they develop in urbanized settings. The interactions that occur within the larger rhizosphere may not only influence tree growth, but also play a role in certain ecosystem services that trees provide, such as treatment of stormwater, that are now taking on a heightened importance.

2. Soil contamination. Urban infill development is growing in importance as societies seek to protect increasingly scarce agricultural and forested land from development and to rehabilitate previously developed land. Thus, professionals who work with urban trees will be increasingly faced with managing trees on sites that are undergoing rehabilitation, such as brownfields. Although considerable information concerning tree roots and contaminated soils is available from phytoremediation and mine spoils research, this work focuses on maximizing extraction of contaminants by trees and other plants with the intention of eventually harvesting the plant and safely disposing of it. Little is known about long-term challenges to growing trees in contaminated soils and the long-term effects of tree roots on contaminated soils.

3. Climate change. There is a growing body of scientific evidence demonstrating that global temperature is increasing, atmospheric $\mathrm{CO}_{2}$ levels are rising, $\mathrm{N}$ deposition from the atmosphere is increasing, and urban heat islands are generating ground-level ozone. All of these factors affect root growth and development either directly or indirectly through mediation from the aboveground portion of the plant. What will be the responses of tree root systems in this altered environment?

The urban ecosystem is under increasing scrutiny as society strives to manage the environment in a sustainable way. Urban trees play a critical role in the urban environment on many levels. As we increase our understanding of the complex processes at play in the rhizosphere, we will not only be able to better manage landscape trees, but also more fully benefit from their role in urban ecosystem processes.

Acknowledgments. We are grateful to many people for their contributions to this project, including Julia Bartens, Francesco Ferrini, Greg McPherson, Paul Markworth, Tang Dai, Gary Watson, and Lisa Richardson-Calfee. We also thank the reviewers for many improvements to the manuscript. This project was supported in part by the International Society of Arboriculture and is a part of the ISA Literature Review Series.

\section{LITERATURE CITED}

Abadía, J., F. Morales, and A. Abadía. 1999. Photosystem II efficiency in low chlorophyll, iron-deficient leaves. Plant and Soil 215(2):183-192.

Abe, K., and M. Iwamoto. 1986. An evaluation of tree-root effect on slope stability by tree-root strength. Journal of the Japanese Forestry Society 68(12):505-510.

Alcántara, E., A.M. Cordeiro, and D. Barranco. 2003. Selection of olive varieties for tolerance to iron chlorosis. Journal of Plant Physiology 160(12):1467-1472.

Altherr, W., D. Blumer, H. Oldörp, and P. Nagel. 2007. How do stakeholders and legislation influence the allocation of green space on brownfield redevelopment projects? Five case studies from Switzer- land, Germany and the UK. Business Strategy and the Environment 16(7):512-522.

Angers, D.A., and J. Caron. 1998. Plant-induced changes in soil structure: Processes and feedbacks. Biogeochemistry 42(1-2):55-72.

Appleton, B.L., and L.T. Chaplin. 2001. New York/Mid-Atlantic Gardener's Book of Lists. Cooper Square Press, Lanham, MD.

Arnold, M.A., and E. Young. 1990. Growth and protein content of apple in response to root and shoot temperature following chilling. HortScience 25:1583-1588.

Aust, W.M., J.A. Burger, G.A. Scheerer, M.D. Tippett, and W.H. McKee, Jr. 1998. Amelioration of compacted and rutted skid trails on wet pine flats: fourth-year results. General Technical Report Southern Research Station 20, USDA Forest Service Asheville, North Carolina 386-391.

Barley, K.P. 1954. Effects of root growth and decay on permeability of synthetic sandy loam. Soil Science Society of America Journal 78:205-211.

Bartens, J., S.D. Day, J.R. Harris, J.E. Dove, and T.M. Wynn. 2008. Can urban tree roots improve infiltration through compacted subsoils for stormwater management? Journal of Environmental Quality 37(6):2048-2057.

Bassett, I., R. Simcock, and N. Mitchell. 2005. Consequences of soil compaction for seedling establishment: Implications for natural regeneration and restoration. Austral Ecology 30(8):827-833.

Bassuk, N. 2008. CU-Soil: An update after more than a decade of use in the urban environment. City Trees (Jan/Feb):16-19.

Bassuk, N., D.F. Curtis, B. Marranca, and B. Neal. 2009. Recommended urban trees: Site assessment and tree selection for stress tolerance. Urban Horticulture Institute, Ithaca, NY.

Bernstein, N., and U. Kafkafi. 2002. Root growth under salinity stress. In: Plant Roots: The hidden half. (3rd Edition) Y. Waisel, A. Eshel, and U. Kafkafi (Ed.). Marcel Dekker, Inc., New York.

Bethlahmy, N. 1962. First year effects of timber removal on soil moisture. Bulletin of the International Association of Scientific Hydrology 7:34-38.

Birch, G.F., and A. Scollen. 2003. Heavy metals in road dust, gully pots and parkland soils in a highly urbanized sub-catchment of Port Jackson, Australia. Australian Journal of Soil Research 41(7):1329-1342.

Bolund, P., and S. Hunhammar. 1999. Ecosystem services in urban areas. Ecological Economics 29:293-301.

Borchert, R. 1994. Soil and stem water storage determine phenology and distribution of tropical dry forest trees. Ecology 75(5):1437-1449.

Boyer, E.W., C.L. Goodale, N.A. Jaworski, and R.W. Howarth. 2002. Anthropogenic nitrogen sources and relationships to riverine nitrogen export in the northeastern U.S.A. Biogeochemistry 57-58(1):137-169.

Bramley, H., J. Hutson, and S.D. Tyerman. 2003. Floodwater infiltration through root channels on a sodic clay floodplain and the influence on a local tree species Eucalyptus largiflorens. Plant and Soil 253(1):275-286.

Brant, J.B., and D.D. Myrold. 2006. Root controls on soil microbial community structure in forest soils. Oecologia 148(4):650-659.

Bronick, C.J., and R. Lal. 2005. Soil structure and management: a review. Geoderma 124(1-2):3-22.

Bunemann, E. K., G. D. Schwenke, and L. Van Sweiten. 2006. Impact of agricultural inputs on soil organisms- a review. Australian Journal of Soil Research 44:379-406.

Buresh, R.J., and G. Tian. 1997. Soil improvement by trees in sub-Saharan Africa Agroforestry Systems 38(1-3).

Burgess, S., M. Adams, N. Turner, D. White, and C. Ong. 2001. Tree roots: conduits for deep recharge of soil water. Oecologia 126:158-165. 
Burgess, S.S.O., M.A. Adams, N.C. Turner, and C.K. Ong. 1998. The redistribution of soil water by tree root systems. Oecologia 115(3):306-311.

Caravaca, F., T. Hernandez, C. Garcia, and A. Roldan. 2002. Improvement of rhizosphere aggregate stability of afforested semiarid plant species subjected to mycorrhizal inoculation and compost addition. Geoderma 108:133-144.

Cheeseman, J. 1988. Mechanisms of salinity tolerance in plants. Annual Review of Plant Physiology 87(547-550).

Clark, L.J., W.R. Whalley, and P.B. Barraclough. 2003. How do roots penetrate strong soil? Plant and Soil 255(1):93-104.

Cripps, J.E.L. 1970. A seasonal pattern of apple root growth in Western Australia. Journal of Horticultural Science 45:153-161.

Czarnes, S., P.D. Hallett, A.G. Bengough, and I.M. Young. 2000. Rootand microbial-derived mucilages affect soil structure and water transport. European Journal of Soil Science 51(3):435-443.

da Silva, A.P., B.D. Kay, and E. Perfect. 1994. Characterization of the Least Limiting Water Range of Soils. Soil Science Society of America Journal 58(6):1775-1781.

Daddow, R. L. and G. E. Warrington. 1983. Growth-limiting soil bulk densities as influenced by soil texture. WSDG-TN-00005. USDA Forest Service Watershed Systems Development Group Fort Collins, Colorado 17

Dasgupta, S., B.P. Mohanty, and J.M. Köhne. 2006. Impacts of juniper vegetation and karst geology on subsurface flow processes in the Edwards Plateau, Texas. Vadose Zone Journal 5(4):1076-1085.

Dawson, T.E. 1993. Hydraulic lift and water-use by plants- implications for water-balance, performance and plant-plant interactions. Oecologia 95:565-574.

Dawson, T.E. 1996. Determining water use by trees and forests from isotopic, energy balance and transpiration analyses: the roles of tree size and hydraulic lift. Tree Physiology 16(1-2):263-272.

Day, S.D., and N.L. Bassuk. 1994. A review of the effects of soil compaction and amelioration treatments on landscape trees. Journal of Arboriculture 20(1):9-17.

Day, S.D., N.L. Bassuk, and H. van Es. 1995. Effects of four compaction remediation methods for landscape trees on soil aeration, mechanical impedance and tree establishment. Journal of Environmental Horticulture 13(2):64-71.

Day, S.D., J.R. Seiler, and N. Persaud. 2000. A comparison of root growth dynamics of silver maple and flowering dogwood in compacted soil at differing soil water contents. Tree Physiology 20(4):257-263.

Day, S.D., P.E. Wiseman, J.R. Harris, and S.B. Dickinson. 2010. Contemporary concepts of root system architecture of urban trees. Arboriculture \& Urban Forestry 36(4):149-159.

de Santiago, A., I. Diaz, M.d.C. del Campillo, J. Torrent, and A. Delgado. 2008. Predicting the incidence of iron deficiency chlorosis from hydroxylamine-extractable iron in soil. Soil Science Society of America Journal 72(5):1493-1499.

De Sousa, C.A. 2003. Turning brownfields into green space in the City of Toronto. Landscape and Urban Planning 62(4):181-198.

Deans, J.D. 1979. Fluctuations of the soil environment and fine root gowth in a young Sitka spruce plantation. Plant and Soil 52:195-208.

Deans, J.D., and E.D. Ford. 1986. Seasonal patterns of radial root growth and starch dynamics in plantation-grown Sitka spruce trees of different ages. Tree Physiology 1:241-251.

Dell, B., and M. Wallace. 1983. Periodicity of fine root growth in Jarrah (Eucalyptus marginata Donn ex Sm.). Australian Journal of Botany 31:247-254.
Dexter, A.R. 1987. Compression of soil around roots. Plant and Soil 97(3):401-406.

Dirr, M.A. 1998. Manual of Woody Landscape Plants: Their Identification, Ornamental Characteristics, Culture, Propagation and Uses. (5th Edition) Stipes Publishing, L.L.C., Champaign, IL.

Docker, B.B., and T.C.T. Hubble. 2008. Quantifying root-reinforcement of river bank soils by four Australian tree species. Geomorphology 100(3-4):401-418.

Dorioz, J.M., M. Robert, and C. Chenu. 1993. The role of roots, fungi and bacteria on clay particle organization. An experimental approach. Geoderma 56(1-4):179-194.

Edwards, W.M., M.J. Shipitalo, L.B. Owens, and L.D. Norton. 1989. Water and nitrate movement in earthworm burrows within long-term no-till corn fields. Journal of Soil Water Conservation 44(3):240-243.

Fakayode, S.O., and B.I. Olu-Owolabi. 2003. Heavy metal contamination of roadside topsoil in Osogbo, Nigeria: Its relationship to traffic density and proximity to highways. Environmental Geology 44(2).

Farmer, R.E.J. 1975. Dormancy and root regeneration of northern red oak. Canadian Journal of Forest Research 5:176-185.

Farrar, J., M. Hawes, D. Jones, and S. Lindow. 2003. How roots control the flux of carbon to the rhizosphere. Ecology 84(4):827-837.

Fogel, R., and G. Hunt. 1983. Contribution of mycorrhizae and soil fungi to nutrient cycling in a Douglas-fir ecosystem. Canadian Journal of Forest Research 13(2):219-232.

Fornara, D.A., D. Tilman, and S.E. Hobbie. 2009. Linkages between plant functional composition, fine root processes and potential soil $\mathrm{N}$ mineralization rates. Journal of Ecology 97:48-56.

Gallagher, F.J., I. Pechmann, J.D. Bogden, J. Grabosky, and P. Weis 2008. Soil metal concentrations and vegetative assemblage structure in an urban brownfield. Environmental Pollution 153:351-361.

Gibbs, R. J. and J. B. Reid. 1988. A conceptual model of changes in soil structure under different cropping systems. Advances in Soil Science 8:123-149

Gilman, E.F., I.A. Leone, and F.B. Flower. 1987. Effect of soil compaction and oxygen content on vertical and horizontal root distribution. Journal of Environmental Horticulture 5(1):33-36.

Gimeno, V., J. P. Syvertsen, M. Nieves, I. Simón, V. Martínez, and F. García-Sánchez. 2009. Additional nitrogen fertilization affects salt tolerance of lemon trees on different rootstocks. Scientia Horticulturae 121(3):298-305.

Godbold, D.L., and A. Hutterman. 1988. Inhibition of photosynthesis and transpiration in relation to mercury-induced root damage in spruce seedlings. Physiologia Plantarum 139:95-99.

Goss, M.J. 1991. Consequences of the activity of roots on soil. In: Plant root growth: an ecological perspective. D. Atkinson (Ed.). Blackwell Scientific Publications, Oxford.

Grayston, S.J., D. Vaughan, and D. Jones. 1997. Rhizosphere carbon flow in trees, in comparison with annual plants: the importance of root exudation and its impact on microbial activity and nutrient availability. Applied Soil Ecology 5(1):29-56.

Greacen, E.L., and R. Sands. 1980. Compaction of forest soils: a review. Australian Journal of Soil Research 18:163-189.

Green, J., L. Dawson, J. Proctor, E. Duff, and D. Elston. 2005. Fine roo dynamics in a tropical rain forest is influenced by rainfall. Plant and Soil 276(1):23-32.

Gregg, J.W., C.G. Jones, and T.E. Dawson. 2003. Urbanization effects on tree growth in the vicinity of New York City. Nature 424:183-187.

Gregory, J.H., M.D. Dukes, P.H. Jones, and G.L. Miller. 2006. Effect of urban soil compaction on infiltration rate. Journal of Soil and Water Conservation 61(3):117-124. 
Groffman, P.M., N.L. Law, K.T. Belt, L.E. Band, and G.T. Fisher. 2004. Nitrogen fluxes and retention in urban watershed ecosystems. Ecosystems 7(4):393-403.

Hagemeyer, J., and S. Breckle. 2002. Trace element stress in roots. In: Plant Roots: The hidden half. (3rd Edition) Y. Waisel, A. Eshel, and U. Kafkafi (Ed.). Marcel Dekker, Inc., New York.

Harris, J.R. 2007. Transplanting large trees. CAB Reviews: Perspectives in Agriculture, Veterinary Science, Nutrition and Natural Resources 2(024).

Harris, J.R., N.L. Bassuk, R.W. Zobel, and T.H. Whitlow. 1995. Root and shoot growth periodicity of green ash, Turkish hazelnut, and tree lilac. Journal of the American Society for Horticulture Science 120:211-216.

Harris, J.R., S.D. Day, and B. Kane. 2008. Nitrogen fertilization during planting and establishment of the urban forest: a collection of five studies. Urban Forestry \& Urban Greening 7(3):195-206.

Harris, J.R., and J. Fanelli. 1999. Root and shoot growth periodicity of pot-in-pot red and sugar maple. Journal of Environmental Horticulture 17:80-83.

Harris, J.R., J. K. Fanelli, and P. Thrift. 2002. Transplant timing affects early root system regeneration of sugar maple and northern red oak. HortScience 37(6):984-987.

Harris, J.R., P. Knight, and J. Fanelli. 1996. Fall transplanting improves establishment of balled and burlapped fringe tree (Chionanthus virginicus L.). HortScience 31:1143-1145.

Harris, J.R., R. Smith, and J.K. Fanelli. 2001. Transplant timing affects first-season root growth of Turkish hazelnut (Corylus colurna L.). HortScience 36:805-807.

Headley, D., and N. Bassuk. 1991. Effect of time and application of sodium chloride in the dormant season on selected tree seedlings. Journal of Environmental Horticulture 9(3):130-136.

Holland, E.A., B.H. Braswell, J. Sulzman, and J. Lamarque. 2005. Nitrogen deposition onto the United States and western Europe: synthesis of observations and models. Ecological Applications 15(1):38-57.

Horn, R., and A.R. Dexter. 1989. Dynamics of soil aggregation in an irrigated desert loess. Soil and Tillage Research 13(3):253-266.

Irvine, K., M. Perrelli, R. Ngoen-klan, and I. Droppo. 2009. Metal levels in street sediment from an industrial city: spatial trends, chemical fractionation, and management implications. Journal of Soils and Sediments 9(4):328-341.

Jama, B., J.K. Ndufa, R.J. Buresh, and K.D. Shepherd. 1998. Vertical distribution of roots and soil nitrate: tree species and phosphorus effects. Soil Science Society of America Journal 62(1):280-286.

Jim, C.Y. 1998. Urban soil characteristics and limitations for landscape planting in Hong Kong. Landscape and Urban Planning 40(4):235-249.

Jobbágy, E., and R. Jackson. 2001. The distribution of soil nutrients with depth: Global patterns and the imprint of plants. Biogeochemistry 53(1):51-77.

Johnson, M.S., and J. Lehmann. 2006. Double-funneling of trees: Stemflow and root-induced preferential flow. Ecoscience 13(3):324-333.

Jones, D.L., A. Hodge, and Y. Kuzyakov. 2004. Plant and mycorrhizal regulation of rhizodeposition. New Phytologist 163(3):459-480.

Kahle, H. 1993. Response of roots of trees to heavy metals. Environmental and Experimental Botany 39:99-119.

Kayama, M., A.M. Quoreshi, S. Kitaoka, Y. Kitahashi, Y. Sakamoto, Y. Maruyama, M. Kitao, and T. Kolke. 2003. Effects of deicing salt on the vitality and health of two spruce species, Picea abies Karst. and Picea glehnii Masters planted along roadsides in northern Japan. Environmental Pollution 124(1):127-137.
Kaye, J.P., P M. Groffman, N.B. Grimm, L.A. Baker, and R.V. Pouyat. 2006. A distinct urban biogeochemistry? Trends in Ecology \& Evolution 21(4): 192-199.

Kaye, J.P., R.L. McCulley, and I.C. Burke. 2005. Carbon fluxes, nitrogen cycling, and soil microbial communities in adjacent urban, native and agricultural ecosystems. Global Change Biology 11(4):575-587.

Krieter, M. 1986. Untersuchungen von Bodeneigenschaften und Wurzelverteilungen an Strassenbaumstandorten (Linde) [Investigations of soil conditions and root distributions of street tree locations]. Das Gartenamt 35:676-678.

Kuhns, M.R., H.E. Garrett, R.O. Teskey, and T.M. Hinkley. 1985. Root growth of black walnut trees related to soil temperature, soil water potential, and leaf water potential. Forest Science 31(3):617-629.

Lafond, J., D.A. Angers, and M.R. Laverdiere. 1992. Compression characteristics of a clay soil as influenced by crops and sampling dates. Soil and Tillage Research 22(3-4):233-241.

Larson, M.M., and F.W. Whitmore. 1970. Moisture stress affects root regeneration and early growth of red oak seedlings. Forest Science $16: 495-498$.

Lee, K.E., and C.E. Pankhurst. 1992. Soil organisms and sustainable productivity. Australian Journal of Soil Research 30(6):855-892.

Lepp, N. 1991. How do trees and other long-lived plants survive in polluted environments? Functional Ecology 5:5-11.

Letey, J. 1985. Relationship between soil physical properties and crop production. pp. 277-294 In: Advances in Soil Science. Vol. 1. Springer-Verlag, New York.

Lloyd, J., J. Syvertsen, and P. Kriedemann. 1987. Salinity effects of leaf water relations and gas exchange of 'Valencia' Orange, Citrus sinensis (L.) Osbeck, on rootstocks with different salt exclusion characteristics. Functional Plant Biology 14(6):605-617.

Lorenz, K., and R. Lal. 2009. Biogeochemical C and N cycles in urban soils. Environmental International 35(1):1-8.

Lyr, H., and G. Hoffmann. 1967. Growth rates and growth periodicity of tree roots International Review of Forestry Research:181-236.

Mamo, M., and G.D. Bubenzer. 2001a. Detachment rate, soil erodibility, and soil strength as influenced by living plant roots part I: Laboratory study. Transactions of the American Society of Agricultural Engineers 44(5):1167-1174.

Mamo, M., and G.D. Bubenzer. 2001b. Detachment rate, soil erodibility, and soil strength as influenced by living plant roots part II: Field study. Transactions of the American Society of Agricultural Engineers 44(5):1175-1181.

Marschner, H. 1996. Mineral Nutrition in Higher Plants. Academic Press, London.

Materechera, S.A., A.R. Dexter, and A.M. Alston. 1991. Penetration of very strong soils by seedling roots of different plant species. Plant and Soil 135:31-41.

McColl, J.G. 1977. Retention of soil water following forest cutting. Soil Science Society of America Journal 41:984-988.

McDonnell, M.J., S.T.A. Pickett, P. Groffman, P. Bohlen, R.V. Pouyat, W.C. Zipperer, R.W. Parmelee, M.M. Carreiro, and K. Medley. 1997. Ecosystem processes along the urban-to-rural gradient. Urban Ecosystems 1(1):21-36.

McGroddy, M., and W.L. Silver. 2009. Variations in belowground carbon storage and soil $\mathrm{CO}_{2}$ flux rates along a wet tropical climate gradient. Biotropica 32(4):614-624.

Meharg, A.A., and K. Killham. 1991. A novel method of quantifying root exudation in the presence of soil microflora. Plant and Soil 133: $111-116$ 
Mengel, K., and E. Kirkby. 2001. Principles of Plant Nutrition. (5th Edition) Kluwer Academic Publishers, Netherlands.

Mitchell, A.R., T.R. Ellsworth, and B.D. Meek. 1995. Effect of root systems on preferential flow in swelling soil. Communications in soil science and plant analysis 26:2655-2666.

Moog, P., and W. Brüggemann. 1994. Iron reductase systems on the plant plasma membrane-A review. Plant and Soil 165(2):241-260.

Mou, P., R.J. Mitchell, and R.H. Jones. 1997. Root distribution of two tree species under a heterogeneous nutrient environment. Journal of Applied Ecology 34:645-656.

Naoto, I., N.M. Quang, I. Takashi, and N. Ryu. 2008. Non-frame method combining with tree root to stabilize natural slope. pp. 457-464. In: Geotechnical Special Publication No. 178. ASCE, New Orleans, Louisiana.

Norris, J.E. 2005. Root reinforcement by hawthorn and oak roots on a highway cut-slope in southern England. Plant and Soil 278(1-2):43-53.

Oliver, L., U. Ferber, D. Grimski, K. Millar, and P. Nathanail. 2005. The scale and nature of European brownfields. In: CABERNET 2005 International Conference on Managing Urban Land LQM Ltd, Nottingham, UK, Belfast, Northern Ireland, UK.

Papdi, C., M.P. Joseph, I.P. Salamó, S. Vidal, and L. Szabados. 2009. Genetic technologies for the identification of plant genes controlling environmental stress responses. Functional Plant Biology 36(8):696720.

Pataki, D.E., T. Xu, Y.Q. Luo, and J.R. Ehleringer. 2007. Inferring biogenic and anthropogenic carbon dioxide sources across an urban to rural gradient. Oecologia 152(2):307-322.

Patra, M., N. Bhowmik, B. Bandopadhyay, and A. Sharma. 2004. Comparison of mercury, lead and arsenic with respect to genotoxic effects on plant systems and the development of genetic tolerance. Environmental and Experimental Botany 52(3):199-223.

Pedersen, L.B., T.B. Randrup, and M. Ingerslev. 2000. Effects of road distance and protective measures on deicing $\mathrm{NaCl}$ deposition and soil solution chemistry in planted median strips. Journal of Arboriculture 26(5):238-245.

Pollen-Bankhead, N., A. Simon, K. Jaeger, and E. Wohl. 2009. Destabilization of streambanks by removal of invasive species in Canyon de Chelly National Monument, Arizona. Geomorphology 103(3):363-374.

Porras-Soriano, A., M.L. Soriano-Martín, A. Porras-Piedra, and R. Azcón. 2009. Arbuscular mycorrhizal fungi increased growth, nutrient uptake and tolerance to salinity in olive trees under nursery conditions. Journal of Plant Physiology 166(13):1350-1359.

Porter, W., A. Robson, and L. Abbott. 1987. Field survey of the distribution of vesicular-arbuscular mycorrhizal fungi in relation to soil $\mathrm{pH}$. Journal of Applied Ecology 24(2):659-662.

Pouyat, R.V., M.J. McDonnell, and S.T.A. Pickett. 1995. Soil characteristics of oak stands along an urban-rural land-use gradient. Journal of Environmental Quality 24(3):516-526.

Pouyat, R.V., I.D. Yesilonis, and D.J. Nowak. 2006. Carbon storage by urban soils in the United States. Journal of Environmental Quality 35(4):1566-1575.

Priority Substances List Assessment: Road Salt. 2001. Canadian Environmental Protection Act 1999 Environment Canada: Health Canada.

Pulford, I.D., and C. Watson. 2003. Phytoremediation of heavy metalcontaminated land by trees--a review. Environment International 29(4):529-540.

Randrup, T.B., E.G. McPherson, and L.R. Costello. 2001. Tree root intrusion in sewer systems: review of extent and costs. Journal of Infrastructure Systems 7(1):26-31.
Richardson-Calfee, L.E., J.R. Harris, and J.K. Fanelli. 2004. Seasonal effects of transplanting on northern red oak and willow oak. Journal of Environmental Horticulture 22(2):75-79.

Richardson-Calfee, L.E., J.R. Harris, and J.K. Fanelli. 2007. Posttransplant root and shoot growth periodicity of sugar maple. Journal of the American Society for Horticultural Sciences 132(2):147-157.

Richardson-Calfee, L.E., J.R. Harris, and J.K. Fanelli. 2008. Root and shoot growth response of balled-and-burlapped and pot-in-pot sugar maple to transplanting at five phenological growth stages. Journal of Environmental Horticulture 26(3):171-176.

Richardson, S.D. 1958. Bud dormancy and root development in Acer saccharinum. pp. 409-425 In: Physiology of Forest Trees. K.V. Thimann (Ed.) Ronald Press, New York.

Richter, D.d., N.-H. Oh, R. Fimmen, and J. Jackson. 2007. The rhizosphere and soil formation. pp. 179-200. In: The Rhizosphere: An Ecological Perspective. Z.G. Cardon and J.L. Whitbeck (Ed.) Academic Press, Amsterdam.

Roberts, J. 1976. A study of root distribution and growth in a Pinus sylvestris L. (Scots pine) plantation in Thetford Chase, Anglia. Plant and Soil 44:607-621.

Roberts, J., N. Jackson, and M. Smith. 2006. Tree Roots in the Built Environment. Vol. 8. Research for Amenity Trees The Stationery Office, London.

Rogerson, T.L. 1976. Soil water deficits under forested and clearcut areas in northern Arkansas. Soil Science Society of America Journal 40:802-805.

Saunier, R.E., and R.F. Wagle. 1967. Factors affecting the distribution of shrub live oak (Quercus turbinella Greene). Ecology 48(1):35-41.

Scharenbroch, B.C., J.E. Lloyd, and J.L. Johnson-Maynard. 2005. Distinguishing urban soils with physical, chemical, and biological properties. Pedobiologia 49(4):283-296.

Schoonover, J.E., B.G. Lockaby, and B.S. Helms. 2006. Impacts of land cover on stream hydrology in the west Georgia piedmont, USA. Journal of Environmental Quality 35(6):2123-2131.

Schroeder, K. 2005. Konkurrenz unter Tage [Competition underground] GruenForum.LA 4:34-38.

Siegel-Issem, C.M., J.A. Burger, R.F. Powers, F. Ponder, and S.C. Patterson. 2005. Seedling root growth as a function of soil density and water content. Soil Science Society of America Journal 69(1):215-226.

Sieghardt, M., E. Mursch-Radlgruber, E. Paoletti, E. Couenberg, A. Dimitrakopoulus, F. Rego, A. Hatzistathis, and T.B. Randrup. 2005. The Abiotic Urban Environment. In: Urban Forests and Trees. C.C. Konijnendijk, K. Nilsson, T.B. Randrup, and J. Schipperijn (Ed.). Springer, New York

Skinner, A.K., I.D. Lunt, P. Spooner, and S. McIntyre. 2009. The effect of soil compaction on germination and early growth of Eucalyptus albens and an exotic annual grass. Austral Ecology.

Stone, E.C., J.L. Jenkinson, and S.L. Krugman. 1962. Root-regenerating potential of Douglas-fir seedlings lifted at different times of year. Forest Science 8:288-297.

Stone, E.C., and G.H. Schubert. 1959. Root regeneration potential of ponderosa pine lifted at different times of the year. Forest Science $5: 322-332$.

Stone, E.L., and P.J. Kalisz. 1991. On the maximum extent of tree roots. Forest Ecology and Management 46(1-2):59-102.

Szabo, A., A. Osztoics, and F. Szilagyi. 2001. Natural wastewater treatment in Hungary. Water Science Technology 44(11-12):331-338.

Tackett, J.L. and R.W. Pearson. 1964. Oxygen requirements of cotton seedling roots for penetration of compacted soil cores. Proceedings of the Soil Science Society of America 28:600-605. 
Takahashi, T., Y. Amano, K. Kuchimura, and T. Kobayashi. 2008. Carbon content of soil in urban parks in Tokyo, Japan Landscape and Ecological Engineering 4(2):139-142.

Taylor, H.M., and H.R. Gardner. 1963. Penetration of cotton seedling taproots as influenced by bulk density, moisture content, and strength of soil. Soil Science 96(3):153-156.

Taylor, H.M., and L.F. Ratliff. 1969. Root elongation rates of cotton and peanuts as a function of soil strength and soil water content. Soil Science 108(2):113-119.

Taylor, J.S., and E.B. Dumbroff. 1975. Bud, root, and growth regulator activity in Acer saccharum. Planta 104:110-114.

Teskey, R.O., and T.M. Hinkley. 1981. Influence of temperature and water potential on root growth of white oak. Physiologia Plantarum 52(3):363-369.

Thaler, P., and L. Pagès. 1998. Modelling the influence of assimilate availability on root growth and architecture. Plant and Soil 201:307-320.

Thornley, J. 1972. A model to describe the partitioning of photosynthate during vegetative plant growth. Annals of Botany 36:419-430.

Tian, C.Y., G. Feng, X.L. Li, and F.S. Zhang. 2004. Different effects of arbuscular mycorrhizal fungal isolates from saline or non-saline soil on salinity tolerance of plants. Applied Soil Ecology 26(2):143-148.

Tisdall, J.M., B. Cockroft, and N.C. Uren. 1978. The Stability of Soil Aggregates as Affected by Organic Materials, Microbial Activity and Physical Disruption. Australian Journal of Soil Research 16(1):9-17.

Turner, A., and N. Dickinson. 1993. The survival of Acer psuedoplatanus L. (sycamore maple) seedlings on metalliferous soils. New Phytologist 123:509-521.

Usman, A.R.A., Y. Kuzyakov, and K. Stahr. 2004. Dynamics of organic $\mathrm{C}$ mineralization and the mobile fraction of heavy metals in a calcareous soil incubated with organic wastes. Water, Air, \& Soil Pollution 158(1):401-418

Verkade, S.D., and D.F. Hamilton. 1983. Effects of benomyl on growth of Liriodendron tulipifera L. Seedlings inoculated with the vesicular-arbuscular fungus, Glomus fasciculatus. Scientia Horticulturae 21(3):253-260.

Violina, R.A., S.I. Angel, and M.B. Dimitar. 1999. Heavy metals ( $\mathrm{Pb}, \mathrm{Cu}$, $\mathrm{Zn}$ and $\mathrm{Cd}$ ) in the system soil - grapevine - grape. Journal of the Science of Food and Agriculture. (5). Online. <http://dx.doi.org/10.1002/ (SICI)1097-0010(199904)79:5<713::AID-JSFA229>3.0.CO;2-F>

Voorhees, W.B., D.A. Farrell, and W. E. Larson. 1975. Soil strength and aeration effects on root elongation. Soil Science Society of America Proceedings 39:948-953.

Waldron, L.J., and S. Dakessian. 1981. Soil reinforcement by roots: calculation of increased soil shear resistance from root properties. Soil Science Society of America Journal 132:427-435.

Waldron, L.J., and S. Dakessian. 1982. Effect of Grass, Legume and Tree Roots on Soil Shearing Resistance. Soil Science Society of America Journal 46:894-899.

Waldron, L.J., S. Dakessian, and J. A. Nemson. 1983. Shear Resistance Enhancement of 1.22-Meter Diameter Soil Cross Sections by Pine and Alfalfa Roots. Soil Science Society of America Journal 47:9-14.

Wargo, P.M. 1983. Effects and consequences of stress on root physiology. Journal of Arboriculture 9:173-176.

Watson, G., and E.B. Himelick. 2004. Effects of soil pH, root density, and tree growth regulator treatments on pin oak chlorosis. Journal of Arboriculture 30(3):172-178.

Wullschleger, S.D., F.C. Meinzer, and R.A. Vertessy. 1998. A review of whole-plant water use studies in tree. Tree Physiol 18(8-9):499-512.
Wynn, T., and S. Mostaghimi. 2006. The effects of vegetation and soil type on streambank erosion, southwestern Virginia, USA. Journal of American Water Resources 42(1):69-82.

Wynn, T.M., S. Mostaghimi, J.A. Burger, A.A. Harpold, M.B. Henderson, and L. Henry. 2004. Variation in root density along stream banks. Journal of Environmental Quality 33(6):2030-2039.

Xiao, Q., and E. McPherson. 2003. Rainfall interception by Santa Monica's municipal urban forest. Urban Ecosystems 6:291-302.

Xiao, Q., G. McPherson, S.L. Ustin, and M.E. Grismer. 2000. A new approach to modeling tree rainfall interception. Journal of Geophysical Research 105(D23):29,173-129,188.

Young, A. 1997. Agroforestry for soil management. (2nd Edition) CAB International Wallingford, United Kingdom.

Young, I.M. 1998. Biophysical interactions at the root \pm soil interface: a review. Journal of Agricultural Science 130(1):1-7.

Yunusa, I.A.M., P.M. Mele, M.A. Rab, C.R. Schefe, and C.R. Beverly. 2002. Priming of soil structural and hydrological properties by native woody species, annual crops, and a permanent pasture. Australian Journal of Soil Research 40(2):207-219.

Zhu, W., N.D. Dillard, and N.B. Grimm. 2004. Urban nitrogen biogeochemistry: status and processes in green retention basins. Biogeochemistry 177(2):177-196.

Zimpfer, J., G. Kennedy, C. Smyth, J. Hamelin, E. Navarro, and J.O. Dawson. 1999. Localization of Casuarina-infective Frankia near Casuarina cunninghamiana trees in Jamaica. Canadian Journal of Botany 77(9):1248-1256.

Zisa, R.P., H.G. Halverson, and B.B. Stout. 1980. Establishment and early growth of conifers on compact soils in urban areas. NE-451. USDA Forest Service

Zwieniecki, M.A., and M. Newton. 1995. Roots growing in rock fissures: their morphological adaptation. Plant and Soil 172(2):181-187.

Susan D. Day (corresponding author)

Department of Forest Resources \& Environmental Conservation and Department of Horticulture

Virginia Tech

310 Cheatham Hall

Blacksburg, VA, 24061, U.S

sdd@vt.edu

S.B. Dickinson

Department of Horticulture

Virginia Tech

dickinso@vt.edu

P.E. Wiseman

Department of Forest Resources \& Environmental Conservation

Virginia Tech

pwiseman@vt.edu

J.R. Harris

Department of Horticulture

Virginia Tech

rharris@vt.edu 
Résumé. Cet article fait une revue des connaissances courantes sur comment les caractéristiques des matériaux et infrastructures en sous-sol des milieux urbains peuvent affecter les racines des arbres tout comme sur comment les racines des arbres contribuent aux processus biogéochimiques dans cet environnement. Les caractéristiques communes dans l'environnement urbain inclues la compaction du sol ainsi que les autres obstacles physiques à l'exploration racinaire, le $\mathrm{pH}$ élevé, les patrons de température et d'humidité altérés, et la présence de contaminants. Ces conditions peuvent altérer les dynamiques de croissance, la morphologie ainsi que la physiologie des racines. En même temps, les racines ont un impact profond sur l'environnement du sol puisqu'elles redirigent de $40 \%$ à $73 \%$ du carbone assimilé dans le sol. L'écologie de la rhizosphère urbaine est un sujet suscitant un intérêt renouvelé pour la recherche, non seulement en raison de son rôle critique dans l'écosystème urbain, mais aussi pour son rôle dans les questions environnementales globales. En plus de sa contribution évidente pour la croissance au-dessus de la surface du sol, l'exploration racinaire de l'environnement pédologique peut avoir une influence sur la capacité environnementale du sol en regard de sa structure et de son drainage via les contributions par les racines. L'influence des racines sert de plus d'intermédiaire grâce au rôle des racines dans l'activité biologique du sol et de ce fait dans le stockage du carbone et le cycle des éléments nutritifs. Les avancés courantes ainsi que les implications des recherches émergentes sont discutées.

Zusammenfassung. Dieser Rückblick untersucht gegenwärtige Erkenntnisse, wie die Untergrundbeschaffenheit von urbanen Einrichtungen die Baumwurzeln beeinflusst und wie Baumwurzeln zu den biogeochemischen Prozessen in dem Untergrund beisteuern. Die typische Bodenbeschaffenheit im urbanen Umfeld umfasst Bodenverdichtung und andere physische Hindernisse gegenüber der Wurzelausbreitung, veränderte Temperatur- und Feuchtigkeitsbedingungen und das Vorkommen von Kontaminationen. Diese Bedingungen können die Wachstumsdynamik, Morphologie und Physiologie von Wurzeln verändern. Gleichzeitig haben Wurzeln einen profunden Einfluss auf die Bodenumwelt, mit
Bäumen, die 40\%-73\% ihres assimilierten Kohlenstoffs in den Untergrund abgeben. Die Ökologie der urbanen Rhizosphäre ist der Kernpunkt eines wieder erwachenden Interesses der Forschung, nicht nur wegen seiner kritischen Rolle im urbanen Ökosystem sondern auch wegen seines Anteils an globalen Umweltfragen. Zusätzlich zum offensichtlichen Beitrag zum oberirdischen Wachstum, kann die Ausbreitung von Wurzeln im Boden einen Beitrag zur Nachhaltigkeit durch Beeinflussung der Bodenstruktur und der Drainage leisten. Der Einfluss der Wurzeln ist weiter bestimmt durch die besondere Rolle der Wurzeln in bodenbiologische Aktivitäten und Kohlenstoffspeicherung und Nährstoffkreislauf. Gegenwärtige Fortschritte und Implikationen einer weiterzuentwickelnden Forschung werden hier diskutiert.

Resumen. Esta revisión examina los avances acerca de cómo las características del subsuelo de los ambientes urbanos afectan a las raíces de los árboles; así como también las raíces de los árboles contribuyen a los procesos biogeoquímicos en este ambiente. Las características de los suelos más comunes en un ambiente urbano incluyen la compactación del suelo y otros impedimentos físicos para la exploración de las raíces, $\mathrm{pH}$ elevado, temperatura elevada, patrones de humedad alterados, asî como la presencia de contaminantes. Estas condiciones pueden alterar la dinámica de crecimiento, morfología y fisiología de las raíces. Al mismo tiempo, las raíces tienen un efecto profundo en el ambiente del suelo, direccionando 40\%-73\% de carbón asimilado debajo del terreno. La ecología de la rizosfera urbana es un tópico de interés renovado para la investigación no solamente debido a su papel crítico en el ecosistema urbano, sino también por su papel en el ambiente global. Además del crecimiento subterráneo es obvio que la exploración de las raíces en el suelo puede influir en la sustentabilidad ambiental a través de las contribuciones de las raíces a la estructura y drenaje del suelo. La influencia de la raíz es por tanto medida por su papel en la actividad biológica del suelo y su almacenaje de carbono y reciclaje de nutrientes. Se discuten los avances actuales e implicaciones para la investigación emergente. 